Science)
http://dergipark.org.tr/ijaws

Araştırma Makalesi

\title{
Bazı Hıyar (Cucumis sativus L.) Çeşit ve Tiplerinde Gynogenesis Yolu ile Haploid Embriyo ve Bitki Eldesi
}

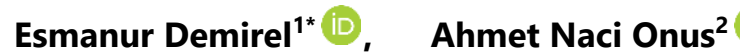 \\ ${ }^{1}$ Akdeniz Üniversitesi, Kumluca Meslek Yüksekokulu, Antalya \\ ${ }^{2}$ Akdeniz Üniversitesi, Ziraat Fakültesi, Bahçe Bitkileri Bölümü, Antalya \\ Geliş tarihi (Received): 12.07.2021 Kabul tarihi (Accepted): 08.09.2021
}

\begin{abstract}
Anahtar kelimeler:
Biyoteknoloji, ıslah, haploid, genotip etkisi, ovaryum kültürü

\section{*Sorumlu yazar}

esmanurdemirel@akdeniz.edu.tr

Özet. Haploid embriyo ve bitkilerin üretimini birçok faktör belirlemektedir. Donör bitki genotipi ve tipide bu faktörler arasında gösterilebilir. Hıyar üzerinde daha önce yapılan çalışmalarda, haploid embriyo ve bitki oluşumundaki başarının birçok faktöre bağlı olduğunu açıkça göstermiştir. Bu nedenle bu çalışma, hıyar türleri ve genotiplerinin haploid embriyo ve bitki eldesi üzerine etkilerini ortaya koymak amacıyla yapılmıştır. Bitki materyali olarak 2 farklı hıyar tipi (kokteyl ve Beith Alpha) ve 5 farklı hıyar çeşidi (Çengel F1, Ufuk F1, Sedir F1, Amisos F1, PTK 40) amaca hizmet etmek üzere kullanılmıştır. Haploid embriyo ve bitki eldesi için ovaryum kültürü tekniği uygulanmıştır. Çiçek açım döneminden 1 gün veya 6 saat önce toplanan ovaryumlar, MS ortamı ve vitaminleri, 1: 10; 2,4-D: Kinetin hormonları ile kombine edilmiş besi ortamında embriyo teşviki için 14 gün bekletilmiştir. Ardından ovaryumlar, MS besi ortamı ve vitaminleri, 1: 4; NAA: BAP hormonları ile modifiye edilmiş besi ortamına bitki rejenerasyonu için aktarılmıştır. Embriyo ve bitki eldesi açısından genotipler arasında ciddi farklar görülmüş olup, çalışmaya göre en yüksek yanıt Çengel F1 çeşidinden alınmış olup, \% 494.44 oranında embriyo ve \% 302.78 oranında bitki oluşmuştur. Bunun yanı sıra PTK 40 çeşidinin embriyo oluşumuna, Ufuk F1 çeşidinin ise haploid bitki oluşumuna en düşük yanıt veren çeşitler olduğu belirlenmiştir. Kokteyl tipinin, Beith Alpha tipine göre daha yüksek yanıt oranına sahip olduğu, ancak genotip etkisinin, tip etkisine göre haploidizasyonu daha yüksek oranda etkilediği düşünülmektedir.
\end{abstract}

\section{Obtaining Haploid Embryo and Plant by Gynogenesis in Some Cucumber (Cucumis sativus L.) Cultivars and Types}

\begin{abstract}
Keywords:
Biotechnology, breeding, haploid, genotype effect, ovarium culture
\end{abstract}




\section{GíRiş}

Dünya nüfusunun hızla artması hem beslenme sorununa, hem de üretim alanlarının daralmasına neden olmaktadır. Bunun sonucunda insanoğlu, birim alandan en yüksek verimle kaliteli ürün elde etme üzerine arayışlar içine girmiştir. İnsan sağlığı açısından önemli su ve besin kaynağı olan hıyar, sofralık ve turşuluk olarak tüketilmenin yanında kozmetik sanayinde de hammadde olarak kullanılmaktadır. Bitki sebze ıslahında dünyada ve ülkemizde en çok geliştirilmeye çalışılan sebzelerden olan hıyar (Cucumis sativus L.) bitkisi insan sağlığı ve beslenmesi açısından oldukça önemli bir bitkidir. $100 \mathrm{~g}$ hıyar meyvesi sadece 12 kalori içermektedir. Kalorisinin düşük olması diyet programlarında tercih edilmesine neden olmakla birlikte, alkali yapısı hayvansal gıdaların insanda oluşturduğu asitliliği giderir. Dünyada 2.231 .402 ha alanda hıyar üretimi yapılmaktadır. 2019 yılı toplam hıyar üretim miktarı ise 87.805.086 tondur. Dünyada en fazla hıyar üreten ülke yaklaşık olarak 70 milyon ton ile Çin olurken, Türkiye ise 1.916.645 ton ile en fazla hıyar üreten ikinci ülke konumundadır (FAO, 2019).

Son yıllarda tarımsal biyoteknolojik faaliyetler kapsamında haploid hıyar bitkilerinin üretilmesi, hıyar ıslah çalışmalarına ivme kazandırmada önemli bir olgu haline gelmektedir. Tek gen seti bulunduran haploid bitkiler, aynı dizilime sahip yeni bir gen setinin kopyalanması ile double haploid hale getirilmektedir. Böylelikle kısa zamanda homozigot bitki hatları elde edilmektedir.

Haploid hıyar bitki eldesinde parthenogesis (Shariatpanahi ve Ramezanpour, 2019), androgenesis (Abdollahi ve ark., 2016) ve gynogenesis (Erol ve Sarı, 2019) yöntemleri kullanılmaktadır. Androgenesis yöntemleri sonucunda sınırlı sayıda bitki üretilmesi ve ıslah hatlarının çoğunlukla gynogenecious hatlar olması sebebiyle, araştırmacılar parthenogenesis ve gynogenesis yöntemlerini kullanmaya yönelmiştir. Hıyar ovaryum kültürü çalışmalarında başarı frekansı; donör bitkiye bağlı unsurlara (genotip, bitki yaşı vb.), ön uygulama koşullarına, besi ortamı içeriğine, kültür koşullarına göre değişmektedir (Diao ve ark., 2009; Li ve ark., 2012). Besi ortamına eklenen poliamin etkinliğinin de genotipe göre değişiklik gösterebileceği bir araştırmada görülmüştür (Wei ve ark., 2010). Farklı termal şok uygulamaları, farklı hormon türevi ve konsantrasyonları karşılaştııılan bir çalışmada yerel bir İran genotipi ile hıyar ıslah hatları kıyaslanmış ve genotipin etki oranının farklı termal şok ve hormon düzeylerine göre değiştiği, yerel genotipin embriyo ve kallus oluşturma düzeyinin yüksek olduğu sonucuna varılmıştır (Golobadi ve ark., 2017). Tek bir besi ortamı protokolü kullanarak hıyar ovaryumlarını kültüre alan Domblides ve ark., (2019b), donör bitki olarak belirlenen 8 farklı ümitvar hıyar genotipinden hepsinde kallus elde ederken, sadece 6 genotipte bitki rejenerasyonu gözlemlemişlerdir. Ayrıca araştırmacılar en yüksek embriyo ve bitki oluşum oranının genotiplere göre farklılık gösterdiğini bildirmektedirler.

Ticari değeri yüksek genotiplerin ve tiplerin haploidizasyon etkinliğinin incelenmesi ıslah firmaları için büyük bir avantaj haline gelebilir. Çalışmalarda genel anlamda genotipler üzerinde durulmuş ancak tipin etki oranlarından çok bahsedilmemiştir. Bu sebeple bu çalışmada farklı ticari hibrit çeşitlerin ve tiplerin sabit bir besi ortamına verdikleri embriyo oluşum ve bitkiye dönüşüm tepkilerinin incelenmesi üzerine araştırma yürütülmüştür. Bu çalışmanın hıyar gynogenesis çalışmalarında donör bitkiyi belirlemede yarar sağlayacağı düşünülmektedir.

\section{MATERYAL VE METOT}

Hıyar çeşit ve tiplerinin gynogenesis yolu ile embriyo oluşum ve bitki oluşum başarı oranlarını belirlemek amacı ile 2 farklı tipte, beş farklı çeşitte donör bitki belirlenmiş ve denemelere alınmıştır. Laboratuvar çalışmaları Akdeniz Üniversitesi Ziraat Fakültesi Bahçe Bitkileri Bölümü Bitki Doku Kültürü Laboratuvarında yürütülmüştür. Genotip değerlendirilmesinde donör olarak belirlenen çeşitler Çengel F1 hibrit çeşidi (Rijk Zwaan Tohum), PTK 40 hibrit çeşidi (Petektar Tohum), Amisos F1 hibrit çeşidi (Altın Tohum), Ufuk F1 hibrit çeşidi (Genetika Tohum), Sedir F1 hibrit çeşididir (Genetika Tohum). Çengel F1, PTK 40 ve Sedir F1 çeşitleri kokteyl tip olup, Amisos F1 ve Ufuk F1 çeşitleri Beith Alpha tip hıyar tiplerine sahiptir.

\section{Dişi Çiçeklerin Toplanması}

Daha önceden yürütmüş olduğumuz çalışmaya dayanarak uygun ovaryum aşaması çiçek açımına yakın dönem olarak planlanmış ve çiçekler anthesisden (çiçek açım zamanı) 1 gün ve 6 saat önce toplanmıştır (Çetinkaya, 2015). Çiçeklerin toplanması saplarından uzaklaştırılarak yapılmış olup, taç yaprak vb. unsurlar laboratuvar ortamında temizlenmiştir. Şekil 1'de farklı aşamalarda bulunan ovaryumlar verilerek, gelişim aşamaları altlarında belirtilmiştir. 


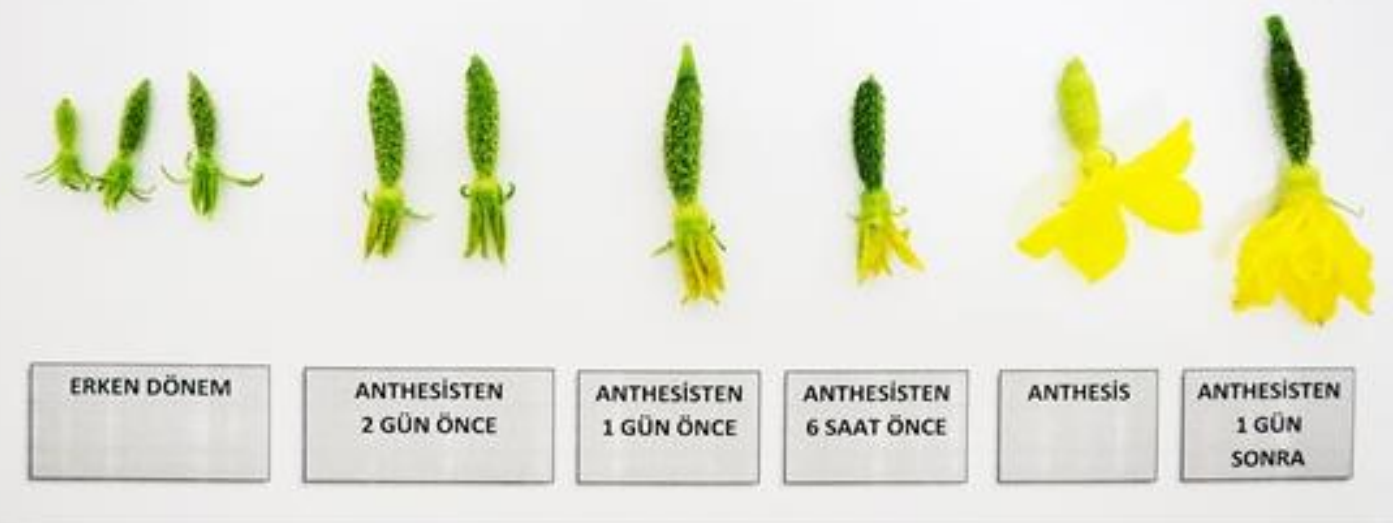

Şekil 1. Farklı aşamalarda olan hıyar dişi çiçeklerinin görüntüsü.

Figure 1. Image of cucumber female flowers at different stages.

\section{Besi Ortamlarının Hazırlanması}

Bu çalışmada embriyo teşvikini sağlamak amacı ile ovaryum kültüründe daha önceden etkili olduğu belirlenen besi ortamı kombinasyonu kullanılmıştır (Çetinkaya, 2015). Temel besi ortamı olarak MS ortamı ve vitaminleri (Murashige ve Skoog, 1962) 1: 10; 2,4-D: Kinetin hormonları ile kombine edilmiştir. Ovaryumlardan gelişen embriyoların bitkiye dönüşümünün olabilmesi için MS besi ortamı 1: 4; NAA: BAP hormonlarıyla kombine edilmiş ve yine bu ortama da $30 \mathrm{~g} \mathrm{~L}^{-1}$ sakkaroz ve $7 \mathrm{~g} \mathrm{~L}^{-1}$ agar eklenerek, $\mathrm{pH}$ seviyesi 5.8 olarak ayarlanmıştır (Çetinkaya, 2015). Gelişen bitkiler organ gelişimlerinin sağlıklı olabilmesi için içeriğinde $1 / 2 \mathrm{MSO}+30 \mathrm{~g} \mathrm{~L}^{-1}$ sükroz ve $7 \mathrm{~g} \mathrm{~L}^{-1}$ agar bulunan sürgün besi ortamlarına aktarılmıştır. Ayrıca tüm besi ortamı kombinasyonlarına $30 \mathrm{~g}^{-1}{ }^{-1}$ sakkaroz ve $7 \mathrm{~g} \mathrm{~L}^{-1}$ agar eklenmiş ve ortamların pH seviyesi 5.8 olarak ayarlanmıştır. Besin ortamları 20 dakika $121^{\circ} \mathrm{C}$ otoklavda sterilize edilmiştir.

\section{Ovaryumların Sterilizasyonu}

Kültüre alınacak ovaryumların taç yaprakları ovaryumdan uzaklaştırılarak, önce sabun ile muamele edilmiş ardından, çeşme suyu ile durulanmış ve steril kabin içerisine aktarılmıştır. Kabin içi sterilizasyonu için ovaryumlar \%70'lik ethanol çözeltisinde 1 dakika, 100 ml'sine \%3'lük sodyum hipoklorit ( $\mathrm{NaClO}$ ) çözeltisi içerisinde 20 dakika bekletildikten sonra 3 kez steril distile sudan geçirilmiş ve böylelikle yüzey sterilizasyonu gerçekleştirilmiştir.

\section{Ovaryumların Kültüre Alınması}

Sterilizasyon işlemi yapılan ovaryumların dış yüzeyleri steril pens ve bistüri yardımı ile ovüllere zarar vermeyecek şekilde soyularak besi ortamından faydalanma oranı artııılmaya çalışılmıştır. Üzerinde ovül bulundurmak şartıyla ovaryumlar 4 eşit parçaya ayrılmış ve her bir ovaryum $60 \mathrm{~mm}$ çapında, içinde besi ortamı olan petrilere dikilmiştir.

\section{Ovaryum Ön Sıcaklık Stresi ve Kültüre Alınan Ovaryumun Gelişim Koşulları}

Ovaryumlar ortamlara alındıktan sonra 3 gün $35^{\circ} \mathrm{C}$ karanlıkta inkübatörde, 2 gün daha $25{ }^{\circ} \mathrm{C}$ sıcaklıkta karanlıkta büyüme odası koşullarında bekletilerek embriyo teşviki sağlanmıştır. Örnekler ön uygulama işlemlerinden sonra $25^{\circ} \mathrm{C}$ sıcaklıkta, 16 saat ışık / 8 saat karanlık periyotta, 3000 lüx'lük floresan lambalar (beyaz gün ışığı) altında iklimlendirme koşullarında gelişim sağlaması için bekletilmiştir.

\section{Ovaryumların Bitki Rejenerasyon Ortamına Aktarılması}

Embriyo teşvik ortamında kültüre alınan eksplantlar kültüre alınma tarihinden 14 gün sonra rejenerasyon ortamına aktarılmıştır.

\section{Bitkilerin Sürgün Ortamına ve Toprağa Aktarılması}

Ovaryumlarda 1-2 cm boyunda sürgünler gözlendiğinde, bitkicikler sürgün besi ortamına aktarılmıştır. Böylelikle bitkiciklerin gelişmesi sağlanarak, ilerde oluşabilecek hormondan kaynaklı mutasyonların önüne geçilmesi amaçlanmıştır. Sürgün ortamında gelişme göstermiş bitki örneği Şekil 3'de verilmiştir. Yaklaşık 4-5 gerçek yaprağa ulaşan bitkiler ise toprağa aktarılarak adaptasyonu sağlanmıştır. 
Ploidi Seviyesinin Belirlenmesi, Embriyo ve Bitkilerin Görüntülenmesi, Çalışma Değerlendirme Yöntemi

Gelişen bitkilerin ploidi seviyeleri stomadaki kloroplast sayım yöntemine LEICA marka ışık mikroskobu yardımı ile 100X ölçeğine göre belirlenmiştir. Ovaryumlardaki değişimler LEICA marka stereo mikroskobu ile görüntülenmiş olup, görüntü büyüklüğü $1.00 \mathrm{X}, 0.80 \mathrm{X}$ ve $1.63 \mathrm{X}$ olarak ölçeklendirilmiştir. Kültüre alınan genotiplerin ovaryumlarında sabit bir oranda eksplant denemeye alınmadığından istatistiksel olarak hesaplanamamış ve sonuçlar oransal olarak verilmiştir.

\section{BULGULAR VE TARTIŞMA}

Haploid embriyo ve bitki eldesi çalışmalarında genotipin önemli bir belirleyici faktör olduğu birçok çalışmada açıç̧a belirtilmiştir (Taşkın ve ark., 2013; Baktemur ve ark., 2014; Plapung ve ark., 2014b). Hıyar gynogenesis çalışmalarında genotipin ve tipin etki oranının belirleyebilmek adına yürüttüğümüz bu çalışmada da genotipin etkisi net bir şekilde görülmüştür. Çalışmada 3 farklı kokteyl tip, 2 farklı Beith Alpha tip F1 hibrit hıyar çeşitleri donör bitki olarak belirlenmiştir. Çeşitler açısından embriyo oluşum yüzdeleri incelendiğinde en yüksek embriyo oluşumu \%494.44 oran ile Çengel F1 çeşidinde tespit edilirken, en düşük embriyo oluşumu \% 16.67 oran ile PTK 40 F1 çeşidinde saptanmıştır. Embriyo oluşumunda Çengel çeşidindeki embriyo oluşum oranını Beith Alpha tip olan Amisos F1 çeşidi takip ederken (\%130.56), bu oran Sedir F1 çeşidinde \% 101.27 olarak bulunmuştur (Şekil 2).

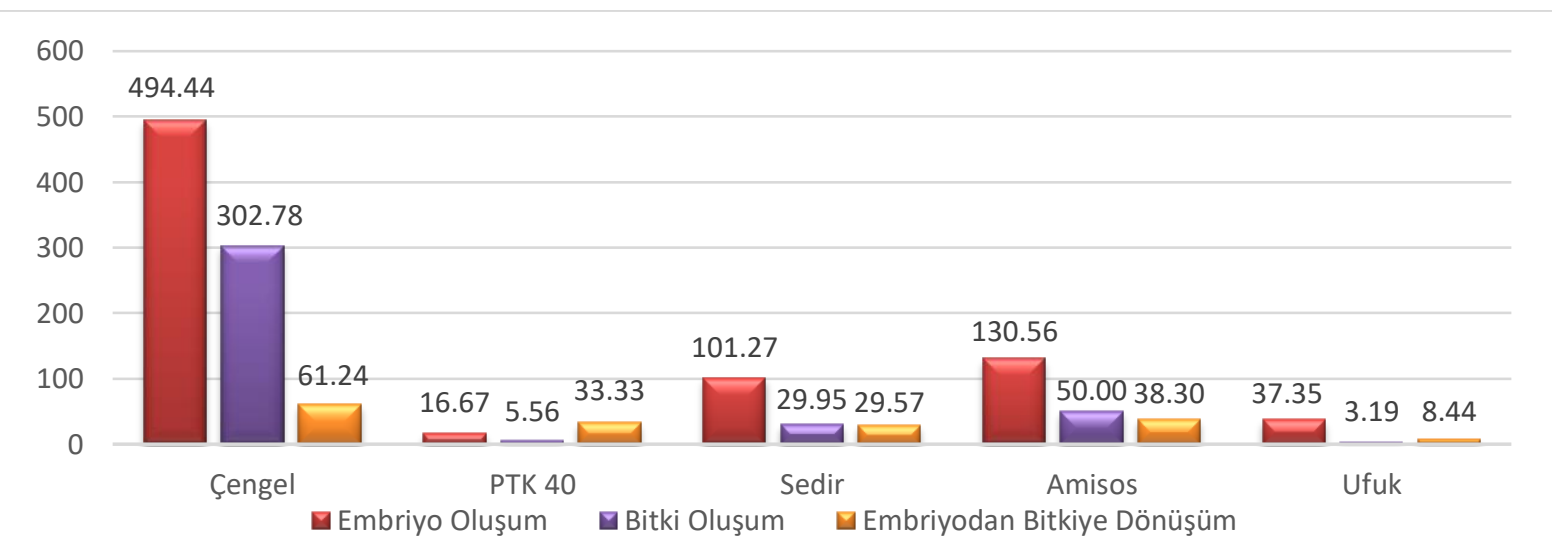

Şekil 2. Çeşitlere göre embriyo oluşum, bitki oluşum ve embriyodan bitkiye dönüşüm başarı oranları (\%).

Figure 2. Success rates of embryo formation, plant formation and embryo-to-plant transformation (\%) by cultivars.

Kültüre alınan ovaryum sayısına göre elde edilen bitki sayısı oranlanmış ve bitki oluşum oranları bulunmuştur. Araştırma sonunda embriyo eldesinde olduğu gibi bitki oluşum oranında en yüksek oluşum Çengel F1 çeşidinde olurken (\%302.78), ikinci en yüksek bitki eldesi \% 50.00 ile Amisos F1 çeşidinde saptanmıştır. En düşük bitki oluşum yanıtı ise Ufuk F1 çeşidinde \%3.19 olarak görülmüştür. Ufuk F1 ve PTK 40 F1 (\%5.56) çeşitlerinde oldukça sınırlı oranda bitki oluşumu gerçekleşmiştir. Sedir F1'de ise bitki oluşum oranı \%29.95 olarak bulunmuştur.

Elde edilen embriyo sayılarına göre bitkiye dönüşüm oranları hesaplandığında ise en yüksek dönüşüm yine diğer değerlendirme kriterlerinde olduğu gibi \%61.24 ile Çengel F1 olurken, ikinci en yüksek oran \% 38.30 ile Amisos F1 çeşidinde gerçekleşmiştir. Üçüncü embriyodan bitkiye dönüşüm oranı ise genel anlamda embriyo ve bitki elde oranı düşük olan PTK 40 F1 çeşidinde (\%33.33) görülmüştür. Bu genotipi az bir fark ile Sedir F1 çeşidi (\%29.57) izlerken, en düşük embriyodan bitkiye dönüşüm oranı ise \% 8.44 ile Ufuk F1 çeşidinde belirlenmiştir. Gelişen embriyolar ve embriyoların farklılaşması ile direkt oluşan bitkicikler, embriyojenik kalluslardan oluşan indirekt bitkicikler Şekil 3'de verilmiştir.

Çeşitlere göre embriyo oluşum, bitki oluşum ve embriyodan bitkiye dönüşüm oranlarında bariz farklılıklar görülmüştür. Bu üç değerlendirme kıstası bakımından en yüksek yanıt veren çeşit Çengel F1 olurken, ikinci en yüksek yanıt ise Amisos F1 çeşidinde tespit edilmiştir. Embriyo oluşum ve bitki oluşum oranlarında üçüncü olan Sedir F1 çeşidi (\%29.57), embriyodan bitkiye dönüşüm oranı açısından PTK 40 F1 (\% 33.33) çeşidinin gerisinde kalarak dördüncü sıraya yerleşmiştir. Bu da embriyoların bitkiye dönüşüm oranının embriyo oluşum ve bitki oluşum oranlarına bağlı olmadığını göstermektedir. Çeşit tepki düzeyinin embriyodan bitkiye dönüşümü açısından değişkenlik göstereceği söylenebilir. Embriyo oluşum yüzdesi açısından en az embriyo oluşumu PTK 40 çeşidinde gerçekleşirken, bu çeşidin üçüncü embriyodan bitkiye dönüşüm oranını yakalamış olması bu durumu açıklamaktadır. Bunun yanı sıra Ufuk F1 çeşidi ise bitki oluşum oranı ve embriyodan bitkiye dönüşüm oranı açısından incelendiğinde, en düşük yanıt alınan çeşit olarak belirlenmiştir. Domblides ve ark., (2019b) sekiz farklı hıyar genotipinde yürütmüş olduğu gynogenesis çalışmasında maksimum gynogenesis indüksiyonunun 1810 
nolu genotipte gerçekleştiğini, ancak en yüksek bitki gelişiminin 1763 nolu genotipte olduğunu söylemektedirler. Bunun aksine Sorntip ve ark., (2017), haploid çalışmalarında inatçı genotipleri kültüre almış ve genotipe bağlı olarak embriyo ve bitki oluşumunun çok değişmediğini görmüşlerdir. Ancak çoğu çalışmada, elde ettiğimiz sonuçlara benzer bir durum ile karşılaşılmış ve hıyarda haploid ve bitki eldesinde genotipin önemli bir faktör olduğu belirtilmiştir (Tantasawat ve ark., 2015; Chen ve ark., 2016). Altı farklı hıyar genotipinin kullanıldığı hıyar androgenesis çalışmasında ise genotip ve hormon seviyesi arasındaki ilişkinin kallus oluşturma ve yeşil doku oluşturma açısından etkili bir faktör olduğu ve en iyi yanıtın üç farklı hormon seviyesinde de Speed Way genotipinden alındığını söylenmektedir (El- Maksoud ve ark., 2009). Zou ve ark. (2018), karpuzda yürütmüş oldukları ovaryum kültürü çalışmasında 8 farklı genotipin gynogenesis etkinliğini değerlendirmiş ve donör bitki genotipinin embryogenesis için anahtar faktör olduğunu belirtmiştir.

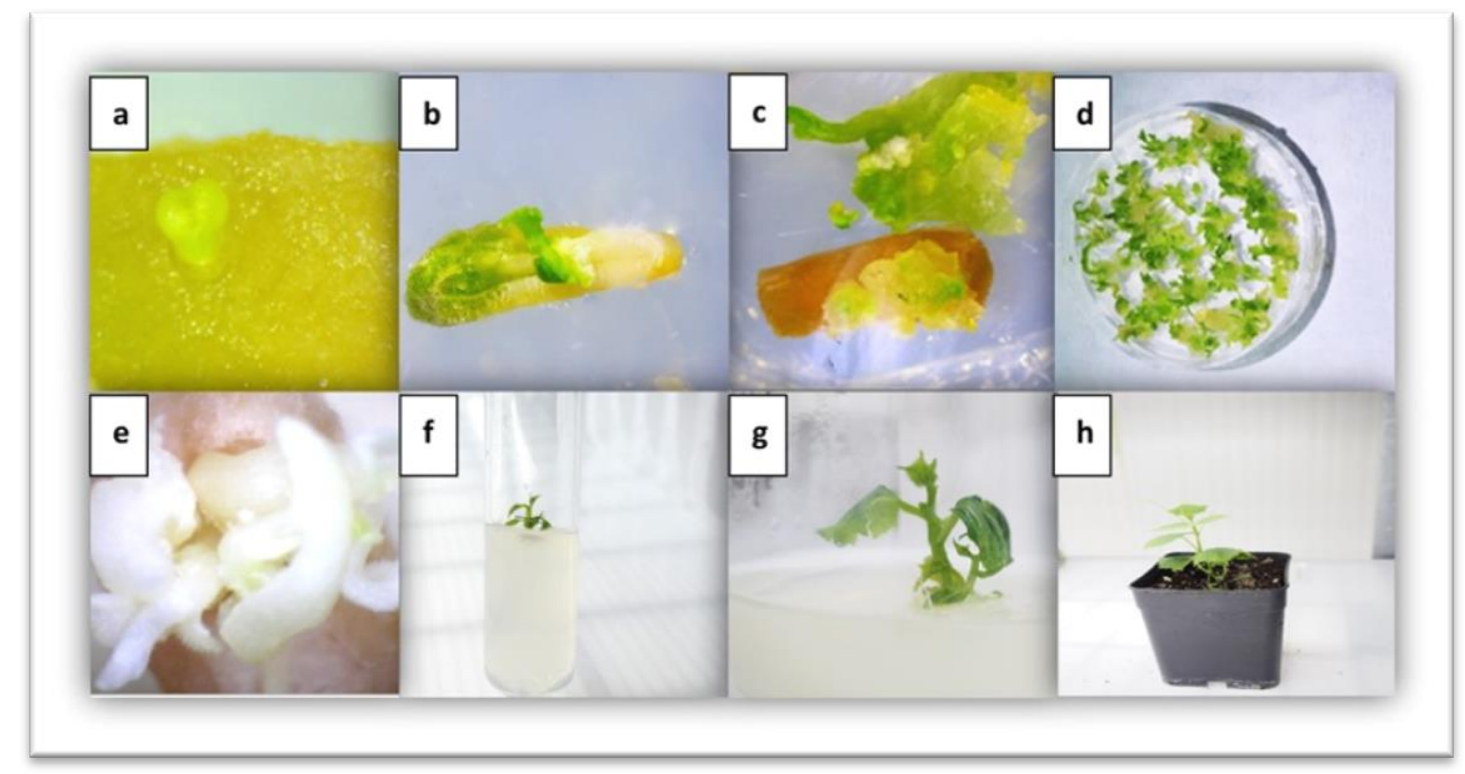

Şekil 3. Çalışmada elde edilen oluşumlar; a) embriyo, b) bitkicik, c) embriyojenik kallus ve bitki dokusu örneği d) embriyojenik kallustan gelişen bitkicikler e) albino bitkicikler f) sürgün ortamına aktarılan bitki g) in vitro ortamda gelişim göstermiş bitki h) toprağa alınmış bitki.

Figure 3. The formations obtained in the study; a) embryo, b) plantlet, c) embryogenic callus and plant tissue sample d) plantlets developing from embryogenic callu, e) albino plantlets f) plant transferred to shoot medium g) plant developed in vitro, h) plant taken into soil.

Tipler bazında inceleme yapıldığında ise üç farklı kokteyl tipin ve iki farkıı Beith Alpha tipin embriyo ve bitki oluşum oranlarının ortalamaları alınmış ve değerlendirmeler buna göre yapılmıştır. Kokteyl tipler genel olarak incelendiğinde embriyo oluşum oranı \%204.13, bitki oluşum oranı ise \% 112.76 olarak tespit edilmiştir. Elde edilen embriyo sayısına göre bitkiye dönüşüm oranı ise $\% 41.38$ olarak belirlenmiştir. Beith Alpha tip hıyarların embriyo oluşum oranı ise \%83.96'dır. Bu tip hıyarların kültüre alınan ovaryum sayısına göre bitki oluşturma yüzdesi ise \%26.60 olarak bulunurken, elde edilen embriyo sayısına göre bitkiye dönüşüm oranı \%23.37 olarak saptanmıştır (Şekil 4).

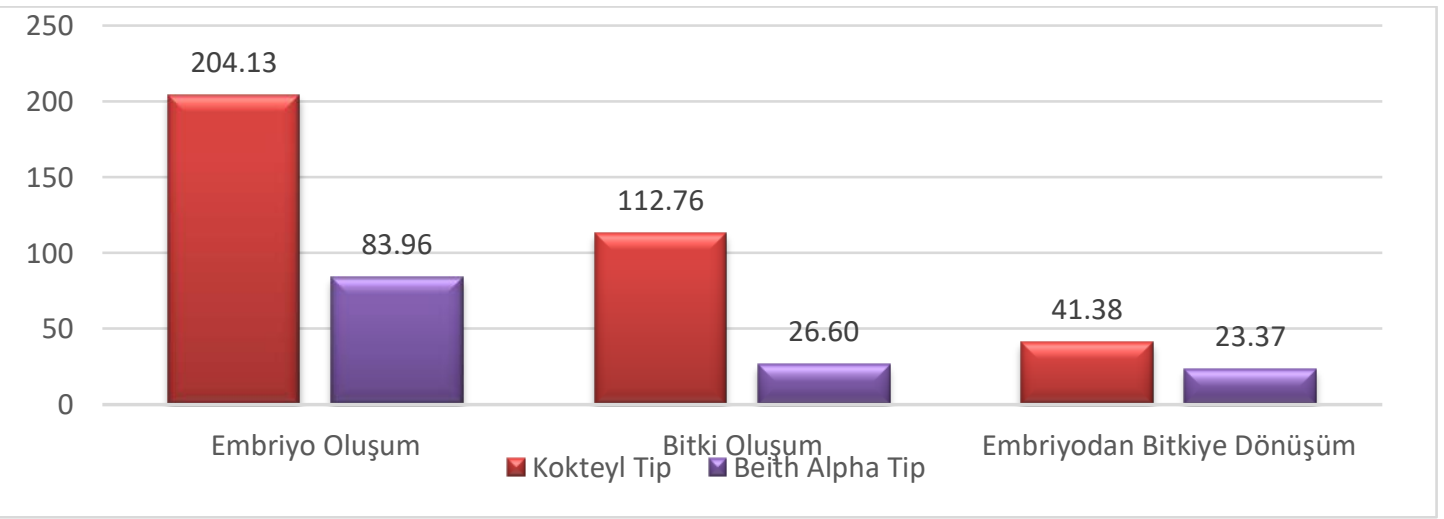

Şekil 4. Hıyar tiplerine göre embriyo oluşum, bitki oluşum ve embriyodan bitkiye dönüşüm oranları (\%).

Figure 4 . Embryo formation, plant formation and embryo-to-plant conversion rates (\%) by cucumber types. 
Tipin hıyar gynogenesis çalışmalarında haploid embriyo ve bitki eldesi için belirleyici bir faktör olduğu açıkça görülmektedir. Kokteyl tip ve Beith Alpha tip arasında tüm değerlendirme kriterlerinde yaklaşık olarak yarı yarıya bir fark görülmüş olup, kokteyl tip hıyarlarının gynogenesis çalışmalarına daha olumlu yanıt vereceği düşünülmektedir. Ancak yürütülen bu çalışmaya göre genotipin tipe göre daha yüksek oranda başarı oranını etkilediği söylenebilir. Çengel F1 ve Sedir F1 kokteyl tiplerinin gynogenesis yanıtı PTK 40 F1 genotipine göre daha yüksek oranda belirlenmiştir. Ayrıca Beith Alpha tip olan Amisos F1 çeşidi, Sedir ve PTK 40 F1 genotipine göre genel anlamda daha yüksek oranda gynogenesise yanıt vermiştir. Bu durum genotipin tipe göre gynogenesis çalışmalarında daha etkili bir faktör olduğunu net bir şekilde ortaya koymaktadır. Domblides ve ark. (2019a)'nın kabak tipleri üzerine yürütmüş oldukları çalışmada da tipe göre embriyo verimlerinin değiştiği, en yüksek embriyonun 55 adet embriyo ile yaz kabağında oluştuğu görülmüştür. Kurtar ve ark. (2018), Cucurbita maxima (kış kabağı) ve Cucurbita moschata'nın (bal kabağı) parthenogenesis ve androgenesis yoluyla başarılı bir şekilde üretildiğini, ancak genotip bağımlılığının yüksek oranda sonucu etkilediğini, ovaryum kültürü çalışmalarında kış kabağından daha yüksek oranda kallus elde edildiği söylemektedirler. Ayrıca araştırmacılar, elde ettiğimiz sonucu destekler neticelere ulaşmış olup, kabak tipinden ziyade genotipin haploid bitki elde etme başarısını daha çok etkilediğini bildirmişlerdir. Şensoy (2011) biber androgenesis çalışmalarında da tipin ve genotipin haploid embriyo ve bitki eldesi çalışmalarının sonucunu etkilediğini, en yüksek embriyo oluşumunun dolmalık biber tipinden gerçekleştiğini, sivri tipinden hiç embriyo oluşmadığı bildirilmektedir. Farklı bitki türlerinde elde edilen bu sonuçlar tipin ve genotipin haploid embriyo ve bitki gelişimini etkilediğini açıkça göstermektedir.

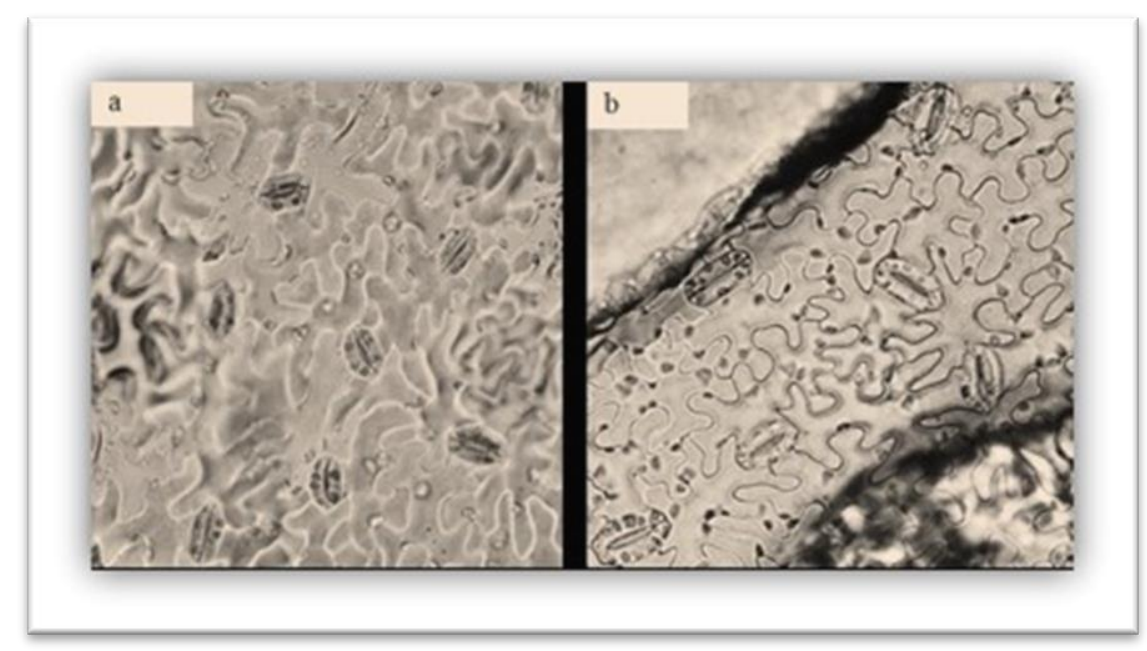

Şekil 5. Stomada kloroplast sayılarının mikroskop ile görüntülenmesi, a) Haploid bitki stoması, b) Diploid bitki stoması. Figure 5. Microscopic visualization of chloroplast numbers in stomata, a) Haploid plant stoma, b) Diploid plant stoma.

Elde edilen bitkilerin ploidi seviyeleri stomadaki kloroplast sayısına göre belirlenmiş ve haploid ve diploid bitkilerin stomaları Şekil 5'de gösterilmiştir. Haploid bitkilerin stomadaki kloroplast sayısı 4-6 adet arasında değiştiği, diploid yapıdaki bitkilerin stomadaki kloroplast sayısı 12-14 adet arasında değiştiği görülmüştür. Çalışma sonucunda stomada kloroplast sayım yöntemi ile ploidi seviyesi belirlenen çeşitlerden Çengel F1'den 71 adet haploid, 8 diploid ve 14 miksoploid, Sedir F1'den 27 adet haploid, 3 diploid ve 1 adet miksoploid, Amisos F1'den 15 adet haploid, 1 diploid ve 4 miksoploid, Ufuk F1'den 10 haploid, 2 diploid, 1 miksoploid ve PTK 40'dan 2 adet haploid bitki tespit edilmiştir.

\section{SONUÇ}

Endüstüriyel ve sofralık üretimde önemli ticari değeri olan hıyar bitkisi, sebze ıslah alanında da üzerinde durulan en önemli bitkiler arasındadır. Islahçıların üstün verimli ve nitelikli hatları geliştirmesi için zaman önemli bir kavramdır. Kısa sürede elde edilen homozigot hatlar ticari çeşitlerin piyasada hemen yer edinmesine olanak sağlamaktadır. Bu sebeple homozigotlaştııımış ıslah hatlarının üretimi için haploid bitki üretim tekniklerini geliştirmeye yönelik farklı çalışmalar yürütülmektedir. Özellikle dişi gametin uyartımı üzerine yürütülen çalışmalarda başarılı sonuçlara ulaşılmaktadır. Yürüttüğümüz bu çalışmada donör bitki genotipi ve tipinin önemi üzerine durulmuş ve farklı sonuçlara ulaşılmıştır. Hıyar haploid embriyo ve bitki eldesi açısından genotipin önemli bir sınırlayıcı faktör olduğu görülmüş ve çalışmada kullanılan beş farklı çeşitten en yüksek yanıt Çengel F1 çeşidinden alınmıştır. Bunun aksine embriyo ve bitki eldesi açısından en düşük yanıt ise PTK 40 F1 çeşidinden elde 
edilmiştir. Hıyar tiplerinin gynogenesis etkinliği üzerine literatürde net bir çalışma bulunamamış olup, elde ettiğimiz sonuçların bundan sonraki çalışmalara yol gösterici nitelikte olacağı düşünülmektedir. Çalışma sonunda kokteyl tipin Beith Alpha tip hıyara göre daha yüksek oranda haploid çalışmasına tepki verdiği görülmüştür. Illerde yapılacak olan çalışmalarda değerlendirilmeye alınmayan diğer tiplerinde embriyo ve bitki oluşturma yüzdeleri açısından karşılaştırılması gerektiği düşünülmektedir. Bu çalışmaya göre tip ve genotip arasındaki önem derecesi değerlendirildiğinde genotipin daha etkili bir faktör olduğu söylenebilir.

\section{ÇIKAR ÇATIŞMASI}

Yazar olarak makalenin planlanması, yürütülmesi ve yazılması konusunda herhangi bir çıkar çatışması olmadığını beyan ederim.

\section{YAZAR KATKISI}

Yazar olarak makalenin planlanması, yürütülmesi ve yazımı doktora danışman hocam Prof. Dr. A. Naci Onus ve tarafımca yapılmıştır.

\section{KAYNAKLAR}

Abdollahi, M. R., Najafi, S., Sarikhani, H., \& Moosavi, S. S. (2016). Induction and development of anther-derived gametic embryos in cucumber (Cucumis sativus L.) by optimizing the macronutrient and agar concentrations in culture medium. Turkish Journal of Biology, 40(3), 571-579.

Baktemur, G., Yücel, N. K., Taşkın, H., Çömlekçioğlu, S., \& Büyükalaca, S. (2014). Effects of different genotypes and gamma ray doses on haploidization using irradiated pollen technique in squash. Turkish Journal of Biology, 38(3), 318-327.

Chen, L., Fu, S. H., Xiang, J., \& Li, Y. (2016). Preliminary studies on the high frequency of double haploid in the ovary culture of cucumber. II Asian Horticultural Congress, China.

Çetinkaya, E., (2015). Farklı besi ortamı kombinasyonlarının bazı hıyar (Cucumis sativus L.) genotiplerinde gynogenesis yolu ile embriyo ve haploid bitki oluşumu üzerine etkisi. Yüksek Lisans Tezi, Akdeniz Üniversitesi, Fen Bilimleri Enstitüsü, Antalya.

Diao, W. P., Jia, Y. Y., Song, H., Zhang, X. Q., Lou, Q. F., \& Chen, J. F. (2009). Efficient embryo induction in cucumber ovary culture and homozygous identification of the regenetants using SSR markers. Scientia Horticulturae, 119(3), 246-251.

Domblides, E. A., Shmykova, N. A., Belov, S. N., Korottseva, I. B., \& Soldatenko, A. V. (2019b). DH-plant production in culture of unpollinated ovules of cucumber (Cucumis sativus L.). Vegetable Crops of Russia, 6, 3-9.

Domblides, E., Shmykova, N., Khimich, G., Korotseva, I., Kan, L., Domblides, A., Pivovarov, V., \& Soldatenko, A. (2019a). Production of doubled haploid plants of Cucurbitaceae family crops through unpollinated ovule culture in vitro. $\mathrm{VI}$ International Symposium on Cucurbits, Belgium.

El-Maksoud, A., EL-Gendy, S. E., \& El-Kady, M. M. (2009). Genotypes and genotypex medium composition interaction effects on androgenetic haploid production in cucumber (Cucumis sativus L.). Journal of Agricultural Chemistry and Biotechnology, 34(11), 10305-10312.

Erol, M. H., \& Sarı, N. (2019). The effect of ovule-ovary culture and spermidine-putrescine applications on haploid embryo induction of cucumber (Cucumis sativus L.). Alatarim, 18(2), 108-117.

FAO, 2019. FAOSTAT Statistic Database. http://www.fao.org. Erişim Tarihi: 02 Mart 2021.

Golabadi, M., Ghanbari, Y., Keighobadi, K., \& Ercisli, S. (2017) Embryo and callus induction by different factors in ovary culture of cucumber. Journal of Applied Botany and Food Quality, 90.

Kurtar, S.E., Balkaya,A., \& Ozer, M. O. (2018). Production of callus mediated gynogenic haploids in winter squash (Cucurbita maxima Duch.) and pumpkin (Cucurbita moschata Duch.). Czech Journal of Genetics and Plant Breeding, 54(1), 9-16.

Li, J. X., Ge, G. M., Pang, S. M., Fang, G. N., Wu, X. B., \& Zhou, H. X. (2012). Study on in vitro Culture and Plantlet Regeneration from Unpollinated Ovary of Cucumis sativus L.[J]. Northern Horticulture, 23.

Murashige, T., \& Skoog, F. (1962). A revised medium for rapid growth and bio assays with tobacco tissue cultures. Physiologia plantarum, 15(3), 473-497.

Plapung, P., Khumsukdee, S., \& Smitamana, P. (2014b). Development of cucumber lines resistant to Cucumber mosaic virus by ovule culture. International Journal of Agricultural Technoogyl, 10(3), 733-741. 
Shariatpanahi, M. E., \& Ramezanpour, S. S. (2019). Induction of parthenogenetic haploid embryos and production of haploid plants in cucumber (Cucumis sativus L.). Journal of Plant Production Research, 26(1), 21-33.

Sorntip, A., Poolsawat, O., Kativat, C., \& Tantasawat, P. A. (2017). Gynogenesis and doubled haploid production from unpollinated ovary culture of cucumber (Cucumis sativus L.). Canadian Journal of Plant Science, 98(2), 353-361.

Şensoy, F. A. (2011). Biberde (Capsicum annuum L.) genotip, bitki yaşı ve mevsimin haploid bitki eldesinde etkisinin araştırlması. Doktora Tezi, Akdeniz Üniversitesi, Fen Bilimleri Enstitüsü, Antalya.

Tantasawat, P. A., Sorntip, A., Poolsawat, O., Chaowiset, W., \& Pornbungkerd, P. (2015). Evaluation of factors affecting embryolike structure and callus formation in unpollinated ovary culture of cucumber (Cucumis sativus). International Journal of Agriculture and Biology, 17(3).

Taşkın, H., Kemal Yücel, N., Baktemur, G., Çömlekçioğlu, S., \& Büyükalaca, S. (2013). Effects of different genotypes and gamma ray doses on haploidization with irradiated pollen technique in watermelon (Citrullus lanatus L.). Canadian Journal of Plant Science, 93(6), 1165-1168.

Wei, A., Du, S., Han, Y., Liu, N., \& Zhang, G. (2010). A study on the relationship between cucumber gynogenesis and content of ovary hormones and polyamines. Acta horticulturae, 871, 625.

Zou, T., Su, H. N., Wu, Q., \& Sun, X. W. (2018). Haploid induction via unfertilized ovary culture in watermelon. Plant Cell, Tissue and Organ Culture (PCTOC), 135(2), 179-187. 